\title{
A phase 1 study of oral ridaforolimus in pediatric patients with advanced solid tumors
}

\author{
Andrew D.J. Pearson ${ }^{1}$, Sara M. Federico², Isabelle Aerts ${ }^{3}$, Darren R. Hargrave ${ }^{4}$, \\ Steven G. DuBois ${ }^{5}$, Robert Iannone ${ }^{6}$, Ryan D. Geschwindt ${ }^{6}$, Ruixue Wang ${ }^{7}$, Frank \\ G. Haluska ${ }^{8}$, Tanya M. Trippett ${ }^{9}$, Birgit Geoerger ${ }^{10}$ \\ ${ }^{1}$ Paediatric Drug Development Unit, Children and Young People's Unit, Institute of Cancer Research, The Royal Marsden NHS \\ Foundation Trust, Sutton, United Kingdom (Retired) \\ ${ }^{2}$ Department of Pediatric Oncology, St. Jude Children's Research Hospital, Memphis, TN, USA \\ ${ }^{3}$ Department of Pediatric, Adolescent and Young Adult Oncology, Institut Curie, Paris, France \\ ${ }^{4}$ Haematology and Oncology Department, Great Ormond Street Hospital for Children, London, United Kingdom \\ ${ }^{5}$ Department of Pediatrics, University of California San Francisco School of Medicine, and Benioff Children's Hospital, San \\ Francisco, CA, USA (current affiliation: Dana-Farber/Boston Children's Cancer and Blood Disorders Center and Harvard \\ Medical School, Boston, MA, USA) \\ ${ }^{6}$ Clinical Research, Merck \& Co., Inc., North Wales, PA, USA \\ ${ }^{7}$ BARDS, MSD R\&D (China) Co. Ltd., Beijing, China \\ ${ }^{8}$ Clinical Research \& Development, ARIAD Pharmaceuticals, Inc., Cambridge, MA, USA \\ ${ }^{9}$ Department of Pediatrics, Memorial Sloan Kettering Cancer Center, New York, NY, USA \\ ${ }^{10}$ Department of Childhood and Adolescent Oncology, Gustave Roussy, University Paris-Sud, Villejuif, France \\ Correspondence to: Andrew D.J. Pearson, email: andylpearson@btinternet.com
}

Keywords: phase I-III trials_pediatric cancers, phase I-III trials_sarcoma/soft-tissue malignancies, ridaforolimus, mTOR, pharmacokinetics Received: June 30, $2016 \quad$ Accepted: September 16, $2016 \quad$ Published: October 04, 2016

\section{ABSTRACT}

Purpose: Ridaforolimus is an investigational, potent, selective mTOR inhibitor. This study was conducted to determine the recommended phase 2 dose (RP2D), maximum tolerated dose, safety, pharmacokinetics, and antitumor activity of oral ridaforolimus in children with advanced solid tumors.

Experimental Design: In this phase 1, multicenter, open-label study in children aged 6 to $<18$ years with advanced solid tumors, ridaforolimus was administered orally for 5 consecutive days/week in 28-day cycles until progression, unacceptable toxicity, or consent withdrawal. Dose started at $22 \mathrm{mg} / \mathrm{m}^{2}$ and increased to $28 \mathrm{mg} /$ $\mathrm{m}^{2}$ and $33 \mathrm{mg} / \mathrm{m}^{2}$, followed by expansion at the RP2D.

Results: Twenty patients were treated; 18 were evaluable for dose-limiting toxicities. One dose-limiting toxicity (grade 3 increased alanine aminotransferase) occurred in 1 patient at $33 \mathrm{mg} / \mathrm{m}^{2}$. Dose escalation concluded at $33 \mathrm{mg} / \mathrm{m}^{2}$; the maximum tolerated dose was not determined. The most common treatmentrelated adverse events (frequency $\geq 40 \%$ ) were manageable grade 1-2 stomatitis, thrombocytopenia, hypertriglyceridemia, increased alanine aminotransferase, fatigue, hypercholesterolemia, anemia, and increased aspartate aminotransferase. Ridaforolimus exposure at $28 \mathrm{mg} / \mathrm{m}^{2}$ and $33 \mathrm{mg} / \mathrm{m}^{2}$ exceeded adult target levels. The RP2D for oral ridaforolimus in children was defined as $33 \mathrm{mg} / \mathrm{m}^{2}$. Four patients received at least 4 cycles; 2 with pineoblastoma and diffuse intrinsic pontine glioma had stable disease for 12 and 46 cycles, respectively.

Conclusions: Ridaforolimus is orally bioavailable and well tolerated in children with advanced solid tumors. The RP2D ( $33 \mathrm{mg} / \mathrm{m}^{2}, 5$ days/week) exceeds the adult RP2D. The favorable toxicity and pharmacokinetic profiles may allow for combination therapy, a promising therapeutic option in pediatric malignancies. 


\section{INTRODUCTION}

The serine/threonine kinase mTOR is a central regulator of cell growth mediated by the phosphatidylinositol 3-kinase (PI3K)/AKT pathway [1-3]. Deregulation of the PI3K/AKT pathway is associated with tumorigenesis in a range of human cancers, including several pediatric malignancies [4-7], and inhibition of this pathway is a promising therapeutic strategy. When tested in the US National Cancer Institute-supported Pediatric Preclinical Testing Program, rapamycin, the prototypic mTOR inhibitor, induced significant differences in event-free survival distributions compared with controls in 27 of 36 in vivo solid tumor models, and objective responses were observed in select osteosarcoma, rhabdomyosarcoma, and rhabdoid tumor xenografts [8]. Inhibition of mTOR decreases VEGF expression in human rhabdomyosarcoma cell lines and xenografts, reduces tumor angiogenesis in human rhabdomyosarcoma xenografts $[9,10]$, and decreases VEGF expression and ezrin-mediated metastatic and invasive behavior in murine osteosarcoma cell lines [11, 12], suggesting that mTOR inhibition may be promising for treatment of sarcomas. Prolonged stable disease was observed in a phase 2 study of single-agent therapy with the mTOR inhibitor temsirolimus in pediatric patients with neuroblastoma and high-grade glioma [13]. Results from a Children's Oncology Group trial in rhabdomyosarcoma demonstrated superior event-free survival in patients randomized to receive treatment with temsirolimus in combination with vinorelbine and cyclophosphamide versus treatment with bevacizumab, vinorelbine, and cyclophosphamide [14]. This growing body of preclinical and clinical evidence has increased interest in mTOR inhibitor therapies for pediatric solid tumors.

Ridaforolimus (formerly deforolimus, AP23573, or MK-8669) is an orally bioavailable non-prodrug analog of rapamycin [15] in clinical development for a variety of solid tumors. Studies have shown that ridaforolimus selectively and potently inhibits mTOR function and proliferative activity in different human tumor cell lines in vitro and tumor xenograft models in vivo, and has synergistic activity when combined with other anticancer agents, such as doxorubicin and carboplatin/paclitaxel $[16,17]$. In phase 1 and 2 trials, ridaforolimus was well tolerated and demonstrated clinical activity in adults with advanced solid tumors, including those with various sarcomas [18-22]. The phase 3 SUCCEED (Sarcoma Multicenter Clinical Evaluation of the Efficacy of Ridaforolimus) trial reported that oral ridaforolimus reduced the risk of progression or death by $28 \%$ compared with placebo in patients with advanced soft tissue and bone sarcomas who had benefited from the immediately preceding cytotoxic chemotherapy [23]. Preliminary data suggest that ridaforolimus is well tolerated and has clinical activity in pediatric patients. In the SUCCEED trial, 7 pediatric patients aged 13 to 17 years received ridaforolimus; 1 had a partial response, 4 had stable disease, and 2 had progressive disease [24]. Results from a phase 1 study in pediatric patients aged 2 to 16 years showed that intravenous ridaforolimus $(8-16 \mathrm{mg} /$ $\mathrm{m}^{2}$ daily for 5 consecutive days every other week) was well tolerated and associated with stable disease in 6 $(40 \%)$ of 15 evaluable pediatric patients with heavily pretreated solid tumors, 4 of 6 with central nervous system tumors and 2 of 8 with sarcomas [25].

The primary objectives of this phase 1 study (NCT01431534) were to define the dose-limiting toxicities (DLTs), maximum tolerated dose (MTD), and recommended phase 2 dose (RP2D), and to characterize the pharmacokinetics of ridaforolimus when orally administered to children and adolescents aged 6 to $<18$ years with advanced solid tumors. Antitumor activity was assessed as a secondary objective. Results from this study informed ridaforolimus dose selection for the companion phase 1 study (NCT01431547), which investigated dalotuzumab monotherapy and ridaforolimus-dalotuzumab combination therapy in pediatric patients with advanced solid tumors [26].

\section{RESULTS}

\section{Patients}

Twenty patients were enrolled and treated at ridaforolimus dose levels of $22 \mathrm{mg} / \mathrm{m}^{2}(n=4), 28 \mathrm{mg} / \mathrm{m}^{2}$ $(n=3)$, and $33 \mathrm{mg} / \mathrm{m}^{2}(n=13)$. Median age was 13 years (range, $8-17$ years) and $60 \%$ of patients were female (Table 1). Tumor diagnoses included: ependymoma in 4 patients ( 1 anaplastic and 3 not otherwise specified); Ewing sarcoma/peripheral primitive neuroectodermal tumor and osteosarcoma in 3 patients each; neuroblastoma in 2 patients; and other diagnoses in 8 patients. Approximately half of the patients had received at least 2 prior anticancer regimens (Table 1). Patients received between 1 and 46 cycles of study treatment (Figure 1). The mean number $( \pm \mathrm{SD})$ of cycles based on ridaforolimus dose levels of 22,28 , and $33 \mathrm{mg} / \mathrm{m}^{2}$ was $4.5 \pm 5.0,2.7$ \pm 1.2 , and $5.7 \pm 12.2$ cycles, respectively; medians and ranges are shown in Table 2. All patients in the $22 \mathrm{mg} /$ $\mathrm{m}^{2}(n=4)$ and $28 \mathrm{mg} / \mathrm{m}^{2}(n=3)$ groups discontinued the study due to progressive disease. In the $33 \mathrm{mg} / \mathrm{m}^{2}(n=13)$ group, 10 patients (77\%) discontinued due to progressive disease, $1(8 \%)$ discontinued due to an adverse event (grade 5 gastric perforation related to underlying disease), and 2 patients $(15 \%$; 1 with pineoblastoma and 1 with diffuse intrinsic pontine glioma) entered the extension study, in which treatment was continued. Four patients received at least 4 courses, 1 with ependymoma (4 cycles at $\left.28 \mathrm{mg} / \mathrm{m}^{2}\right), 1$ with neuroblastoma (7 cycles at $33 \mathrm{mg} /$ 


\begin{tabular}{|c|c|c|c|c|}
\hline & $\begin{array}{c}\text { Total } \\
N=\mathbf{2 0}\end{array}$ & $\begin{array}{l}\text { Ridaforolimus } \\
\begin{array}{c}22 \mathrm{mg} / \mathrm{m}^{2} \\
n=4\end{array}\end{array}$ & $\begin{array}{c}\text { Ridaforolimus } \\
\begin{array}{c}28 \mathrm{mg} / \mathrm{m}^{2} \\
n=3\end{array}\end{array}$ & $\begin{array}{c}\text { Ridaforolimus } \\
\begin{array}{c}33 \mathrm{mg} / \mathrm{m}^{2} \\
n=13\end{array}\end{array}$ \\
\hline Median age, years (range) & $13.0(8-17)$ & $13.5(8-17)$ & $15.0(12-17)$ & $12.0(8-17)$ \\
\hline \multicolumn{5}{|l|}{ Gender, $n(\%)$} \\
\hline Male & $8(40)$ & $1(25)$ & $2(67)$ & $5(38)$ \\
\hline Female & $12(60)$ & $3(75)$ & $1(33)$ & $8(62)$ \\
\hline \multicolumn{5}{|l|}{ Tumor diagnosis, $n(\%)$} \\
\hline Ependymoma (1 anaplastic and 3 NOS) & $4(20)$ & $1(25)$ & $1(33)$ & $2(15)$ \\
\hline $\begin{array}{l}\text { Ewing sarcoma/peripheral primitive } \\
\text { neuroectodermal tumor }\end{array}$ & $3(15)$ & $1(25)$ & 0 & $2(15)$ \\
\hline Osteosarcoma & $3(15)$ & $1(25)$ & $1(33)$ & $1(8)$ \\
\hline Neuroblastoma & $2(10)$ & 0 & 0 & $2(15)$ \\
\hline Other $^{\mathrm{a}}$ & $8(40)$ & $1(25)$ & $1(33)$ & $6(46)$ \\
\hline \multicolumn{5}{|l|}{ Number of prior therapies, $n(\%)$} \\
\hline 1 & $8(40)$ & $2(50)$ & $1(33)$ & $5(38)$ \\
\hline 2 & $3(15)$ & 0 & 0 & $3(23)$ \\
\hline 3 & $3(15)$ & $1(25)$ & 0 & $2(15)$ \\
\hline$\geq 4$ & $4(20)$ & $1(25)$ & $2(67)$ & $1(8)$ \\
\hline Unknown & $2(10)$ & 0 & 0 & $2(15)$ \\
\hline
\end{tabular}

${ }^{a}$ Other includes 1 patient each with: adrenocortical carcinoma; classical Hodgkin lymphoma; diffuse intrinsic pontine glioma; glioblastoma multiforme; pineoblastoma; soft tissue neoplasm, NOS; synovial sarcoma; and Wilms tumor (nephroblastoma).

NOS, not otherwise specified.

$\left.\mathrm{m}^{2}\right), 1$ with pineoblastoma ( 12 cycles at $\left.22 \mathrm{mg} / \mathrm{m}^{2}\right)$, and 1 with diffuse intrinsic pontine glioma ( 46 cycles at $33 \mathrm{mg} /$ $\mathrm{m}^{2}$ as of January 2016).

\section{Dose-limiting toxicity and RP2D}

A total of 18 patients were evaluable for DLTs (Table 2). Two patients were not evaluable for DLTs and were replaced for the DLT analysis only: 1 patient with concomitant administration of a high-dose corticosteroid, which could have affected the determination of DLTs, and 1 patient who had progressive disease before completing the DLT assessment period. One DLT of grade 3 increased alanine aminotransferase (ALT) occurred in 1 patient at the $33 \mathrm{mg} / \mathrm{m}^{2}$ dose. Drug administration was interrupted and the DLT resolved. Dose escalation was stopped at the highest planned dose level explored in this study, $33 \mathrm{mg} / \mathrm{m}^{2}$, and the MTD was not determined. Based on the toxicity profile, pharmacokinetics, and efficacy (all reported below), the RP2D for oral ridaforolimus in children was defined as $33 \mathrm{mg} / \mathrm{m}^{2}$, and the expansion phase was at this dose.

\section{Adverse events}

Nineteen patients (95\%) experienced at least 1 treatment-related adverse event. Table 3 shows treatmentrelated adverse events reported in more than 1 patient. Treatment-related adverse events reported in $\geq 30 \%$ of patients were stomatitis $(75 \%)$, thrombocytopenia (65\%), hypertriglyceridemia $(50 \%)$, increased ALT $(50 \%)$, fatigue $(45 \%)$, hypercholesterolemia $(45 \%)$, anemia $(40 \%)$, increased aspartate aminotransferase (AST) $(40 \%)$, leukopenia $(35 \%)$, nausea $(30 \%)$, and neutropenia (30\%).

Treatment-related grade $3 / 4$ adverse events were reported in 9 patients $(45 \%)$. The most common treatment-related grade $3 / 4$ adverse events were increased ALT (25\%) and thrombocytopenia (10\%). Serious adverse events occurred in 12 patients $(60 \%)$, most of which were disease related. Three patients (15\%) experienced serious adverse events related to study treatment: 1 patient at $22 \mathrm{mg} / \mathrm{m}^{2}$ (grade 3 oral herpes) and 2 patients at $33 \mathrm{mg} / \mathrm{m}^{2}$ (grade 2 rectal pain in 1 patient and grade 2 seizure in 1 patient). Three 


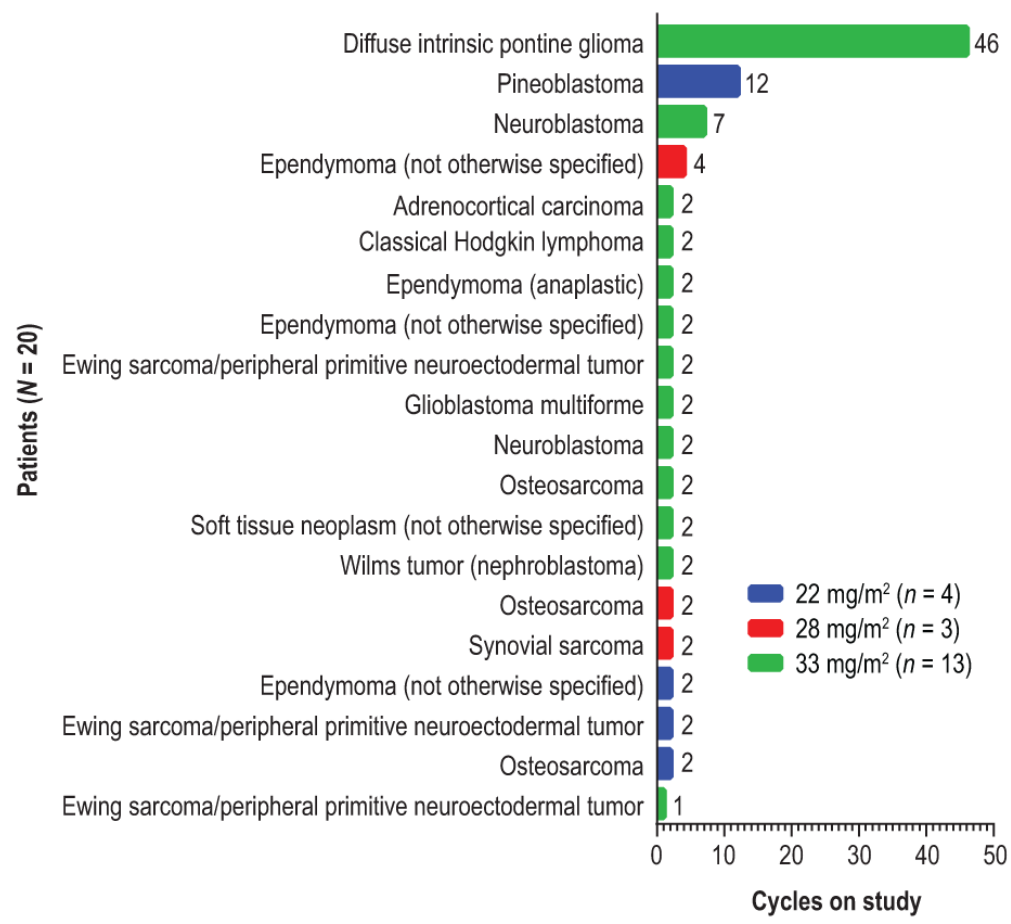

Figure 1: Time on study. Each bar shows the number of 28-day cycles that a patient received the study treatment, oral ridaforolimus $\left(22,28\right.$, or $\left.33 \mathrm{mg} / \mathrm{m}^{2}\right)$ administered once daily for 5 days per week.

Table 2: Dose-escalation and assessment of DLTs in pediatric patients treated with oral ridaforolimus $(N=20)$

\begin{tabular}{|c|c|c|c|c|c|c|}
\hline $\begin{array}{l}\text { Dose } \\
\text { level }\end{array}$ & $\begin{array}{l}\text { Dose, } \\
\mathrm{mg} / \mathrm{m}^{2}\end{array}$ & $\begin{array}{l}\text { Patients } \\
\text { treated, } n\end{array}$ & $\begin{array}{c}\text { Patients } \\
\text { evaluable for } \\
\text { DLT, } n\end{array}$ & $\begin{array}{c}\text { Patients with } \\
\text { DLT, } n\end{array}$ & $\begin{array}{l}\text { Time to DLT } \\
\text { onset, days }\end{array}$ & $\begin{array}{c}\text { Median } \\
\text { (range) time on } \\
\text { therapy, cycles }\end{array}$ \\
\hline 1 & 22 & 4 & 3 & 0 & - & $2(2-12)$ \\
\hline 2 & 28 & 3 & 3 & 0 & - & $2(2-4)$ \\
\hline 3 & 33 & 7 & 6 & $\begin{array}{c}1 \text { (grade } 3 \\
\text { increased ALT) }\end{array}$ & $22($ cycle 1$)$ & $2(1-46)^{a}$ \\
\hline $\begin{array}{l}\text { RP2D } \\
\text { expansion }\end{array}$ & 33 & 6 & 6 & 0 & - & - \\
\hline
\end{tabular}

${ }^{\mathrm{a} C y c l e s}$ on therapy for all patients treated with ridaforolimus $33 \mathrm{mg} / \mathrm{m}^{2}$ during dose escalation and RP2D expansion $(n=13)$.

deaths occurred during the study, 1 due to neurologic symptoms in a patient with central nervous system metastases, 1 due to neoplasm progression, and 1 due to gastric perforation related to underlying disease. No deaths were considered related to ridaforolimus.

\section{Pharmacokinetics}

Blood samples for pharmacokinetic evaluation were collected from all treated patients, and pharmacokinetic data were evaluable for 19 patients. One patient was excluded because no dose was administered on day 5. Mean blood concentrations of ridaforolimus following oral dosing are shown by dose level in Figure 2A, and exposure relative to actual dose is plotted in Figure 2B. Trough concentrations from predose samples on days 1 through 5 indicated that steady-state concentrations had been achieved at day 5 . Absorption occurred after a lag of approximately 2 hours after dosing, and highest blood concentrations were generally observed 4 hours after dosing. Concentrationversus-time profiles were lowest at the $22 \mathrm{mg} / \mathrm{m}^{2}$ dose, but nearly superimposable at the $28 \mathrm{mg} / \mathrm{m}^{2}$ and $33 \mathrm{mg} / \mathrm{m}^{2}$ doses. Exposure at the $28 \mathrm{mg} / \mathrm{m}^{2}$ and $33 \mathrm{mg} / \mathrm{m}^{2}$ dose levels (day 5 area under the concentration-versus-time curve from 0 to 24 hours $\left[\mathrm{AUC}_{0-24 \mathrm{~h}}\right]=2,330$ and 2,280 h•ng/ $\mathrm{mL}$, respectively) was approximately $34 \%$ higher and 


\begin{tabular}{|c|c|c|c|c|c|c|c|c|}
\hline & \multicolumn{2}{|c|}{$\begin{array}{c}\text { Total } \\
N=\mathbf{2 0}\end{array}$} & \multicolumn{2}{|c|}{$\begin{array}{c}\text { Ridaforolimus } \\
\begin{array}{c}22 \mathrm{mg} / \mathrm{m}^{2} \\
n=4\end{array}\end{array}$} & \multicolumn{2}{|c|}{$\begin{array}{c}\text { Ridaforolimus } \\
\begin{array}{c}28 \mathrm{mg} / \mathrm{m}^{2} \\
n=3\end{array}\end{array}$} & \multicolumn{2}{|c|}{$\begin{array}{c}\text { Ridaforolimus } \\
\begin{array}{c}33 \mathrm{mg} / \mathrm{m}^{2} \\
n=13\end{array}\end{array}$} \\
\hline & $\begin{array}{c}\text { Any } \\
\text { grade }\end{array}$ & $\begin{array}{c}\text { Grades } \\
3-4\end{array}$ & $\begin{array}{c}\text { Any } \\
\text { grade }\end{array}$ & $\begin{array}{c}\text { Grades } \\
3-4\end{array}$ & $\begin{array}{c}\text { Any } \\
\text { grade }\end{array}$ & $\begin{array}{c}\text { Grades } \\
3-4\end{array}$ & $\begin{array}{l}\text { Any } \\
\text { grade }\end{array}$ & $\begin{array}{c}\text { Grades } \\
3-4\end{array}$ \\
\hline $\begin{array}{l}\text { Patients with } \geq 1 \text { treatment-related } \\
\text { adverse event }\end{array}$ & $19(95)$ & $9(45)$ & $3(75)$ & $2(50)$ & $3(100)$ & $2(67)$ & $13(100)$ & $5(38)$ \\
\hline \multicolumn{9}{|l|}{ Nonhematologic } \\
\hline Stomatitis & $15(75)$ & 0 & $2(50)$ & 0 & $3(100)$ & 0 & $10(77)$ & 0 \\
\hline Fatigue & $9(45)$ & 0 & $2(50)$ & 0 & $1(33)$ & 0 & $6(46)$ & 0 \\
\hline Nausea & $6(30)$ & 0 & $1(25)$ & 0 & $1(33)$ & 0 & $4(31)$ & 0 \\
\hline Dysgeusia & $3(15)$ & 0 & 0 & 0 & 0 & 0 & $3(23)$ & 0 \\
\hline Headache & $3(15)$ & 0 & 0 & 0 & 0 & 0 & $3(23)$ & 0 \\
\hline Photophobia & $3(15)$ & 0 & 0 & 0 & $1(33)$ & 0 & $2(15)$ & 0 \\
\hline Vomiting & $3(15)$ & 0 & $1(25)$ & 0 & 0 & 0 & $2(15)$ & 0 \\
\hline Decreased appetite & $2(10)$ & 0 & 0 & 0 & 0 & 0 & $2(15)$ & 0 \\
\hline Decreased weight & $2(10)$ & 0 & 0 & 0 & 0 & 0 & $2(15)$ & 0 \\
\hline Diarrhea & $2(10)$ & 0 & 0 & 0 & 0 & 0 & $2(15)$ & 0 \\
\hline Dry mouth & $2(10)$ & 0 & $2(50)$ & 0 & 0 & 0 & 0 & 0 \\
\hline Epistaxis & $2(10)$ & 0 & 0 & 0 & 0 & 0 & $2(15)$ & 0 \\
\hline Oral herpes & $2(10)$ & $1(5)$ & $1(25)$ & $1(25)$ & 0 & 0 & $1(8)$ & 0 \\
\hline Rash & $2(10)$ & 0 & 0 & 0 & $1(33)$ & 0 & $1(8)$ & 0 \\
\hline \multicolumn{9}{|l|}{ Hematologic } \\
\hline Thrombocytopenia $^{\mathrm{a}}$ & $13(65)$ & $2(10)$ & $2(50)$ & 0 & $1(33)$ & $1(33)$ & $10(77)$ & $1(8)$ \\
\hline Anemia $^{a}$ & $8(40)$ & 0 & $2(50)$ & 0 & $1(33)$ & 0 & $5(38)$ & 0 \\
\hline Leukopenia $^{\mathrm{b}}$ & $7(35)$ & 0 & $1(25)$ & 0 & $2(67)$ & 0 & $4(31)$ & 0 \\
\hline Neutropenia $^{a}$ & $6(30)$ & $1(5)$ & $2(50)$ & 0 & 0 & 0 & $4(31)$ & $1(8)$ \\
\hline Lymphopenia ${ }^{a}$ & $2(10)$ & $1(5)$ & $1(25)$ & 0 & 0 & 0 & $1(8)$ & $1(8)$ \\
\hline \multicolumn{9}{|l|}{ Biochemical } \\
\hline Hypertriglyceridemia ${ }^{a}$ & $10(50)$ & $1(5)$ & $2(50)$ & 0 & $1(33)$ & 0 & $7(54)$ & $1(8)$ \\
\hline Increased ALT & $10(50)$ & $5(25)$ & $1(25)$ & $1(25)$ & $1(33)$ & $1(33)$ & $8(62)$ & $3(23)$ \\
\hline Hypercholesterolemia $^{a}$ & $9(45)$ & $1(5)$ & $2(50)$ & 0 & $1(33)$ & $1(33)$ & $6(46)$ & 0 \\
\hline Increased AST & $8(40)$ & $1(5)$ & $1(25)$ & 0 & $1(33)$ & 0 & $6(46)$ & $1(8)$ \\
\hline Hypophosphatemia $^{a}$ & $5(25)$ & $1(5)$ & $2(50)$ & $1(25)$ & $1(33)$ & 0 & $2(15)$ & 0 \\
\hline Increased $\gamma$-glutamyltransferase & $5(25)$ & $1(5)$ & $1(25)$ & 0 & $1(33)$ & 0 & $3(23)$ & $1(8)$ \\
\hline Hyperglycemia $^{a}$ & $2(10)$ & 0 & 0 & 0 & $1(33)$ & 0 & $1(8)$ & 0 \\
\hline Hypocalcemia $^{\mathrm{a}}$ & $2(10)$ & 0 & $1(25)$ & 0 & 0 & 0 & $1(8)$ & 0 \\
\hline Hypokalemia $^{a}$ & $2(10)$ & 0 & $1(25)$ & 0 & $1(33)$ & 0 & 0 & 0 \\
\hline
\end{tabular}




\begin{tabular}{|c|c|c|c|c|c|c|c|c|}
\hline & \multicolumn{2}{|c|}{$\begin{array}{c}\text { Total } \\
N=\mathbf{2 0}\end{array}$} & \multicolumn{2}{|c|}{$\begin{array}{c}\text { Ridaforolimus } \\
\begin{array}{c}22 \mathrm{mg} / \mathrm{m}^{2} \\
n=4\end{array}\end{array}$} & \multicolumn{2}{|c|}{$\begin{array}{c}\text { Ridaforolimus } \\
\begin{array}{c}28 \mathrm{mg} / \mathrm{m}^{2} \\
n=3\end{array}\end{array}$} & \multicolumn{2}{|c|}{$\begin{array}{c}\text { Ridaforolimus } \\
\begin{array}{c}33 \mathrm{mg} / \mathrm{m}^{2} \\
n=13\end{array}\end{array}$} \\
\hline & $\begin{array}{c}\text { Any } \\
\text { grade }\end{array}$ & $\begin{array}{c}\text { Grades } \\
3-4\end{array}$ & $\begin{array}{c}\text { Any } \\
\text { grade }\end{array}$ & $\begin{array}{c}\text { Grades } \\
\text { 3-4 }\end{array}$ & $\begin{array}{c}\text { Any } \\
\text { grade }\end{array}$ & $\begin{array}{c}\text { Grades } \\
3-4\end{array}$ & $\begin{array}{c}\text { Any } \\
\text { grade }\end{array}$ & $\begin{array}{c}\text { Grades } \\
3-4\end{array}$ \\
\hline Increased alkaline phosphatase & $2(10)$ & 0 & $1(25)$ & 0 & 0 & 0 & $1(8)$ & 0 \\
\hline Increased bilirubin & $2(10)$ & 0 & $1(25)$ & 0 & 0 & 0 & $1(8)$ & 0 \\
\hline
\end{tabular}

Numbers are $n(\%)$.

Note: Only the highest reported grade of a given adverse event is counted for an individual patient. Three grade 5 adverse events occurred during the study (neurologic symptoms in a patient with central nervous system metastases, neoplasm progression, and gastric perforation related to underlying disease); none were related to ridaforolimus, according to the investigator. The number of cycles evaluated is shown in Table 2.

${ }^{a}$ Reported as an adverse event by the investigator or based on laboratory values.

bBased on laboratory values only; leukopenia was not reported separately by investigators as a treatment-related adverse event.

A

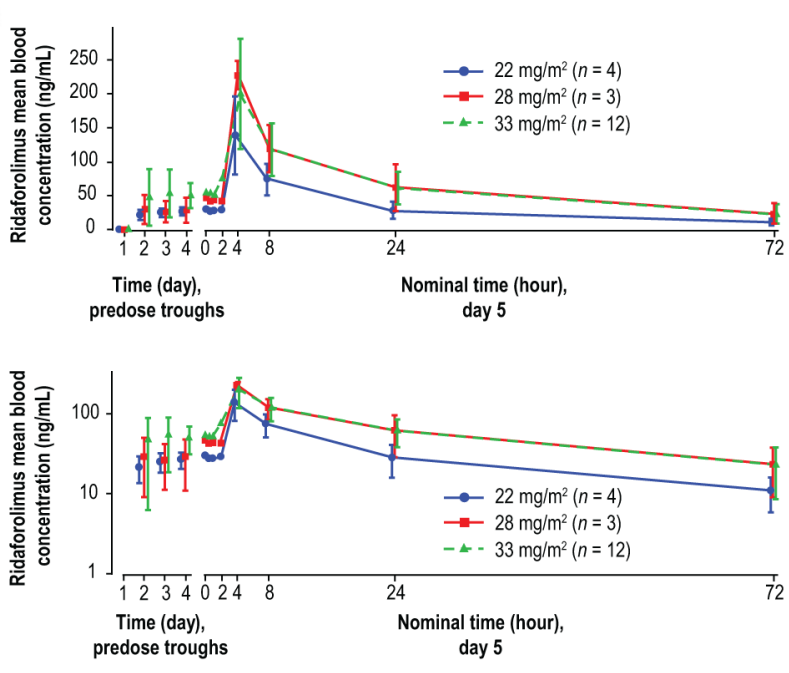

B

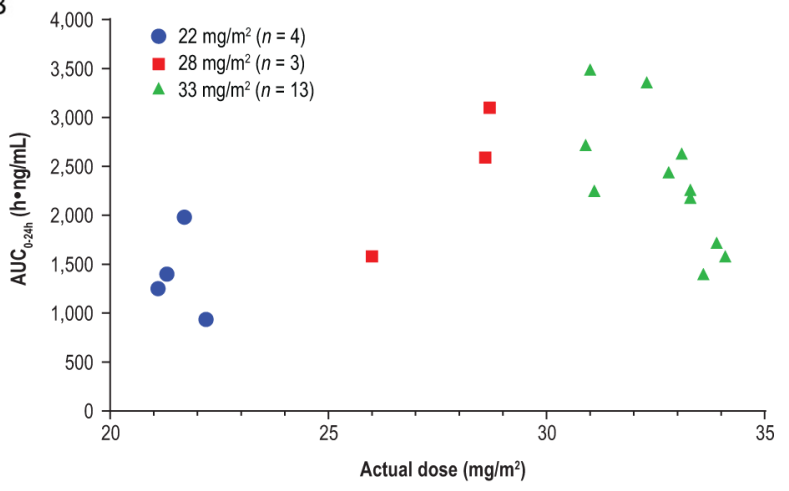

Figure 2: Pharmacokinetic profile of oral ridaforolimus in pediatric patients. A. Mean ( \pm SD) blood concentration of ridaforolimus following oral dosing at 22,28 , and $33 \mathrm{mg} / \mathrm{m}^{2}$ once daily for 5 days per week of a 28 -day cycle in pediatric patients. Top panel: linear scale; bottom panel: semi-log scale. B. Exposure $\left(\mathrm{AUC}_{0-24 \mathrm{~h}}\right)$ relative to actual dose of oral ridaforolimus (calculated based on body surface area) in pediatric patients.

$31 \%$ higher, respectively, than target levels based on the adult RP2D of $40 \mathrm{mg}$ (once daily for 5 days per week) in adults with a mean body surface area (BSA) of $1.8 \mathrm{~m}^{2}$ (day $5 \mathrm{AUC}_{0-24 \mathrm{~h}}=1,739 \mathrm{~h} \bullet \mathrm{ng} / \mathrm{mL}$; data on file with ARIAD Pharmaceuticals, Inc./Merck \& Co., Inc.). Pharmacokinetic parameters are summarized in Table 4. Mean (geometric) elimination half-lives were 26 to 27 hours, independent of dose level. None of the pharmacokinetic parameters appeared to vary with patient age.

\section{Efficacy}

None of the patients had a partial or complete response. However, 4 patients received at least 4 courses. One patient with pineoblastoma had stable disease for 12 cycles at the $22 \mathrm{mg} / \mathrm{m}^{2}$ dose level before disease progression (progression-free survival was 12.8 months). One patient with diffuse intrinsic pontine glioma treated at the $33 \mathrm{mg} / \mathrm{m}^{2}$ dose level continued to receive ridaforolimus with stable disease for 46 cycles as of January 2016.

\section{DISCUSSION}

This is the first trial to evaluate the oral formulation of the mTOR inhibitor ridaforolimus in pediatric patients. In this phase 1 study, ridaforolimus was well tolerated in pediatric patients with advanced malignancies, with only 1 DLT (grade 3 increased ALT) 
Table 4: Pharmacokinetic parameters for blood concentrations of ridaforolimus on day 5 of oral dosing (once daily $\times$ 5 days per week) according to dose level in pediatric patients

\begin{tabular}{|c|c|c|c|}
\hline Pharmacokinetic parameter & $\begin{array}{c}\text { Dose level } 1 \\
22 \mathrm{mg} / \mathrm{m}^{2} \\
(n=4)\end{array}$ & $\begin{array}{c}\text { Dose level } 2 \\
28 \mathrm{mg} / \mathrm{m}^{2} \\
(n=3)\end{array}$ & $\begin{array}{c}\text { Dose level } 3 \\
33 \mathrm{mg} / \mathrm{m}^{2} \\
(n=12)^{\mathrm{a}}\end{array}$ \\
\hline Day $5 \mathrm{AUC}_{0-24 \mathrm{~h}}, \mathrm{~h} \bullet \mathrm{ng} / \mathrm{mL}$ & $n=4$ & $n=3$ & $n=11$ \\
\hline Geometric mean $\left(\mathrm{CV}^{\mathrm{o}}{ }^{\mathrm{b}}\right)$ & $1,340(32)$ & $2,330(36)$ & $2,280(30)$ \\
\hline $\mathrm{C}_{4 \mathrm{~h}}, \mathrm{ng} / \mathrm{mL}$ & $n=4$ & $n=3$ & $n=11$ \\
\hline Arithmetic mean (SD) & $139(57)$ & $228(21)$ & $200(81)$ \\
\hline Geometric mean $\left(\mathrm{CV}^{\mathrm{o}}{ }^{\mathrm{b}}\right)$ & $131(41)$ & $227(10)$ & $184(45)$ \\
\hline $\mathrm{C}_{8 \mathrm{~h}}, \mathrm{ng} / \mathrm{mL}$ & $n=4$ & $n=3$ & $n=12$ \\
\hline Arithmetic mean (SD) & $74(23)$ & $119(35)$ & $118(39)$ \\
\hline Geometric mean $\left(\mathrm{CV}^{\mathrm{b}}{ }^{\mathrm{b}}\right)$ & $71(37)$ & $116(32)$ & $113(32)$ \\
\hline$t_{1 / 2}, h$ & $n=3^{c}$ & $n=3$ & $n=9$ \\
\hline Arithmetic mean (SD) & $25.5(2.8)$ & $28.2(9.5)$ & $26.9(8.7)$ \\
\hline Median (range) & $24.5(23.5-28.7)$ & $26.5(19.7-38.4)$ & $24.9(21.0-49.1)$ \\
\hline Geometric mean $\left(\mathrm{CV}^{\mathrm{b}}{ }^{\mathrm{b}}\right)$ & $25.5(10.5)$ & $27.2(34.5)$ & $26.0(26.7)$ \\
\hline
\end{tabular}

aThirteen patients were enrolled with daily dose administration of ridaforolimus $33 \mathrm{mg} / \mathrm{m}^{2} ; 1$ patient was excluded because of no exposure on day 5. For 1 patient, $\mathrm{AUC}, \mathrm{C}_{4 \mathrm{~h}}$, and $\mathrm{t}_{1 / 2}$ were not evaluable because of limited sampling. For 2 additional patients, $\mathrm{t}_{1 / 2}$ was not evaluable. The geometric mean of BSADN AUC $(n=11)$ was $69.8 \mathrm{~h} \bullet \mathrm{ng} \mathrm{m}^{2} /(\mathrm{mL} \bullet \mathrm{mg})$. The lower bounds of the $90 \% 1$-sided confidence intervals for the geometric means of day $5 \mathrm{AUC}_{0-24 \mathrm{~h}}, \mathrm{C}_{4 \mathrm{~h}}, \mathrm{C}_{8 \mathrm{~h}}, \mathrm{BSADN}$ AUC, and $\mathrm{t}_{1 / 2}$ were $2,020 \mathrm{~h} \bullet \mathrm{ng} / \mathrm{mL}, 154 \mathrm{ng} / \mathrm{mL}, 100 \mathrm{ng} / \mathrm{mL}, 61.2 \mathrm{~h} \bullet \mathrm{ng} \mathrm{m}^{2} /(\mathrm{mL} \bullet \mathrm{mg})$, and $23.0 \mathrm{~h}$, respectively. Backtransformed leastsquares mean and confidence interval were performed on natural log-transformed values.

${ }^{\mathrm{b}} \mathrm{Geometric}$ coefficient of variation, where $\mathrm{CV} \%=100 \times \sqrt{ }\left(\exp \left[\mathrm{S}^{2}\right]-1\right)$ and $\mathrm{S}^{2}$ is the observed variance on the natural logarithmic scale.

'For 1 patient, $\mathrm{t}_{1 / 2}$ was not evaluable.

BSADN AUC, area under the concentration-versus-time curve normalized by BSA-adjusted dose; $\mathrm{C}_{4 \mathrm{~h}}$, concentration at 4 hours; $\mathrm{C}_{8 \mathrm{~h}}$, concentration at 8 hours; $\mathrm{CV} \%$, coefficient of variation as a percentage; $\mathrm{t}_{1 / 2}$, elimination half-life.

at the highest dose of $33 \mathrm{mg} / \mathrm{m}^{2}$ once daily for 5 days per week. Stomatitis and thrombocytopenia were the main treatment-related toxicities and were mostly mild or moderate in severity. Dose escalation was stopped at $33 \mathrm{mg} / \mathrm{m}^{2}$, equivalent to $150 \%$ of the adult $\mathrm{RP} 2 \mathrm{D}$ of $40 \mathrm{mg}$ (assuming an average adult BSA of $1.8 \mathrm{~m}^{2}$ ) [27], and the MTD was not determined. The RP2D for oral ridaforolimus in children was defined as $33 \mathrm{mg} /$ $\mathrm{m}^{2}$, although pharmacokinetic data indicate that $28 \mathrm{mg} /$ $\mathrm{m}^{2}$ also achieves target concentrations and may also be considered for combination treatment.

The toxicity profile for oral ridaforolimus in children in this study is comparable to that observed with intravenous ridaforolimus in previous studies in adults $[20,27]$ and children [25]. In a phase 1 study in pediatric patients with refractory solid tumors, no DLTs were observed with intravenous ridaforolimus $\left(8-16 \mathrm{mg} / \mathrm{m}^{2}\right.$ daily for 5 consecutive days every other week) [25]. The most common adverse events in the intravenous pediatric study, mostly mild to moderate, were thrombocytopenia, anemia, hypertriglyceridemia, leukopenia, elevated AST and ALT, and hypophosphatemia [25]. In adults, DLTs of grade 2 stomatitis and oral mucositis were observed with oral ridaforolimus (the MTD was $40 \mathrm{mg}$ for the once daily $\times 5$ days per week regimen) and intravenous ridaforolimus (MTD, $18.75 \mathrm{mg} / \mathrm{d}$ ) [20, 27]. The most common treatment-related adverse events in adults were grade 1 to 2 mucositis, rash, and anemia with intravenous administration [20] and fatigue and mucosal inflammation with oral administration [27]. Although the pediatric MTD of oral and intravenous ridaforolimus has not been identified, evidence of clinical benefit was noted in 2 $(10 \%)$ of the 20 treated pediatric patients in our study and in $6(40 \%)$ of 15 patients treated with intravenous ridaforolimus, 8 to $16 \mathrm{mg} / \mathrm{m}^{2}$ daily for 5 consecutive days every other week, in a previous pediatric study [25], suggesting that further dose escalation may not be necessary.

Although head-to-head trials have yet to be conducted, the safety profile of oral ridaforolimus may be considered in the context of other mTOR inhibitors evaluated in children with refractory solid tumors. In a 
phase 1 trial of temsirolimus administered once weekly to children with recurrent or refractory solid tumors, 1 DLT (grade 3 anorexia) was observed in 1 of 7 patients who received the highest dose tested $\left(150 \mathrm{mg} / \mathrm{m}^{2}\right)$ [28] and the phase 2 trial was performed at $75 \mathrm{mg} / \mathrm{m}^{2}$, which, as in the ridaforolimus study, was higher than the equivalent adult RP2D but was well tolerated [13]. A phase 1 trial of oral everolimus in children with refractory solid tumors reported DLTs of grade 3 increased ALT $(n=1)$, grade 3 mucositis $(n=1)$, and grade 3 diarrhea $(n=1)$ in 3 of 3 patients treated at the highest dose of $6.5 \mathrm{mg} / \mathrm{m}^{2}$ [29], and the RP2D of $5 \mathrm{mg} / \mathrm{m}^{2}$ is roughly equivalent to the recommended adult dose of $10 \mathrm{mg}$ once daily [29, 30]. Ridaforolimus compares favorably in this study, with 1 DLT reported in 1 patient.

Although limited by the relatively small number of sampling time points, the pharmacokinetic profile of ridaforolimus in whole blood following oral administration to pediatric patients was comparable to that observed in previous studies of oral ridaforolimus in adult patients $[21,27]$. Exposure with the $33 \mathrm{mg} / \mathrm{m}^{2}$ dose in children was approximately $31 \%$ higher than with the RP2D in adults (40 mg once daily, 5 days per week), suggesting that clinically effective concentrations are attained with the $33 \mathrm{mg} / \mathrm{m}^{2}$ dose. The concentrationversus-time profiles for the $28 \mathrm{mg} / \mathrm{m}^{2}$ and $33 \mathrm{mg} / \mathrm{m}^{2}$ doses were nearly superimposable, consistent with previous reports of a nonlinear relationship between dose and ridaforolimus concentration in whole blood [25, 27]. The reason the MTD of ridaforolimus was not reached may have been because higher doses do not produce higher exposures. Rapamycin analogs reach a plateau at higher doses due to saturable binding to intracellular protein FK506-binding protein in red blood cells [25]. The pharmacokinetic plateau observed in whole blood may not be observed in serum, because a higher unbound fraction is expected at higher concentrations due to saturation of FK506-binding protein in the red blood cells. This phenomenon supports the use of $33 \mathrm{mg} / \mathrm{m}^{2}$ rather than $28 \mathrm{mg} / \mathrm{m}^{2}$ as the RP2D. Although the dose could potentially be escalated further because the MTD was not determined, $33 \mathrm{mg} / \mathrm{m}^{2}$ appears to provide an appropriate exposure level in children, given that future development of ridaforolimus may involve combination therapy to increase efficacy.

Prolonged stable disease was observed in 2 patients in this study, 1 patient with pineoblastoma and 1 with diffuse intrinsic pontine glioma, with progression-free survival of 12.8 months and $>42$ months, respectively. This is consistent with observations that ridaforolimus crosses the blood-brain barrier [31] and that the benefit of single-agent therapy with an mTOR inhibitor is characteristically disease stabilization [25, 28, 29], including in patients with diffuse intrinsic pontine glioma [13]. While mTOR inhibitors have generally been associated with modest clinical activity as single-agent therapies, chemotherapy or other targeted agents have shown improved effects and even reversed resistance when combined with an mTOR inhibitor [14, 32, 33]. Preclinical studies of mTOR inhibitors combined with insulin-like growth factor 1 receptor (IGF1R) inhibitors showed additive or synergistic antitumor activity when the agents were combined [34-36], guiding interest in combining ridaforolimus with an anti-IGF1R monoclonal antibody, dalotuzumab. Two phase 1 studies [34, 37] have evaluated ridaforolimus in combination with dalotuzumab in adults and have shown that combining these agents is feasible and that the combination may have synergistic activity in advanced malignancies. A positive effect was not observed in a phase 2 study of ridaforolimus, dalotuzumab, and exemestane versus ridaforolimus and exemestane alone in advanced breast cancer [38]; however, lower doses of ridaforolimus in the first arm may have contributed to this lack of effect. In a phase 1 study of dalotuzumab monotherapy and ridaforolimus-dalotuzumab combination therapy in pediatric patients (NCT01431547), 1 of 20 patients who received dalotuzumab alone achieved a confirmed partial response, and none of the 4 patients who received the ridaforolimus-dalotuzumab combination achieved a response or prolonged stable disease [26]; however, it could be valuable to assess the ridaforolimusdalotuzumab combination in a larger cohort. Ridaforolimus could be combined with other compounds, as well.

Validated biomarkers are not currently available for the prediction of efficacy and the selection of patients for future development of ridaforolimus as an mTOR inhibitor in pediatric oncology. Preclinical models and early-phase clinical trials have suggested that mutations in the PIK3CA gene, PTEN loss of function mutations, and high levels of phosphorylated AKT and phosphorylated S6 ribosomal protein may predict the efficacy of mTOR inhibitors $[39,40]$. Future clinical trials should incorporate the investigation of biomarkers that may be predictive of response to treatment.

In conclusion, ridaforolimus is an investigational, orally bioavailable mTOR inhibitor that is well tolerated in pediatric patients with advanced solid tumor malignancies, with grade 3 increased ALT as a DLT. The safety profile observed in children is comparable to that observed in adults. The RP2D for ridaforolimus in children is $33 \mathrm{mg} / \mathrm{m}^{2}, 5$ days per week, although preliminary pharmacokinetic data suggest that $28 \mathrm{mg} /$ $\mathrm{m}^{2}$ may also be considered. In view of the potency, oral bioavailability, and toxicity profile of ridaforolimus in the current trial, along with similar pharmacokinetic profiles observed with intravenous and oral ridaforolimus in previous studies in children and adults, oral ridaforolimus may be well suited for combination therapy, which may represent an important option for use in pediatric malignancies. 


\section{MATERIALS AND METHODS}

\section{Patients}

Eligible patients were children $\geq 6$ (due to tablet size) to $<18$ years of age at the date of enrollment with histologically or cytologically confirmed malignant solid tumors, including tumors of the central nervous system and lymphoma, that had progressed despite standard therapy or for which no effective standard therapy was known. Patients who had received standard therapy and continued to have biopsy-proven residual stable disease were also eligible. In the absence of a biopsy, patients with sarcoma were eligible on the basis of persistent positron emission tomography activity and patients with neuroblastoma were eligible on the basis of persistent activity by ${ }^{123}$ I-metaiodobenzylguanidine scan. Diagnoses of diffuse intrinsic pontine glioma did not require biopsy. Patients with measurable (per Response Evaluation Criteria in Solid Tumors, version 1.1 [RECIST v1.1]) or nonmeasurable disease were eligible. Patients were required to have a BSA within the acceptable range for a given dose cohort in order to achieve an actual dosing variation of $\leq 2 \mathrm{mg} / \mathrm{m}^{2}$ above or below the target (see dosing nomogram in Supplementary Table S1). Other key inclusion criteria were: Lansky Play Scale score of $\geq 70$ for children $<10$ years of age; Karnofsky performance score of $\geq 70$ for children aged 10 to 15 years; Eastern Cooperative Oncology Group performance status of 0 to 2 for patients $\geq 16$ years of age; absolute neutrophil count of $\geq 1,000 / \mu \mathrm{L}$, platelet count $\geq 75,000 / \mu \mathrm{L}$, serum creatinine level $\leq 1.5$ times the upper limit of normal $(\leq 1.5 \times \mathrm{ULN})$ for age, serum total bilirubin level $\leq 1.5 \times \mathrm{ULN}$ (or direct bilirubin at or below the ULN for patients with total bilirubin $>1.5$ $\times \mathrm{ULN})$, AST and ALT levels $\leq 2.5 \times \mathrm{ULN}(\leq 5 \times \mathrm{ULN}$ in patients with liver metastases), fasting serum glucose level $<160 \mathrm{mg} / \mathrm{dL}$, serum cholesterol level $<350 \mathrm{mg} / \mathrm{dL}$, and fasting triglyceride level $<400 \mathrm{mg} / \mathrm{dL}$. Key exclusion criteria were as follows: uncontrolled intercurrent illness; poorly controlled type 1 or 2 diabetes (fasting glucose level $>160 \mathrm{mg} / \mathrm{dL}$ ); known human immunodeficiency virus, hepatitis $\mathrm{B}$ virus, or hepatitis $\mathrm{C}$ virus infection (testing not required); or persistent acute toxicity (grade $\geq 2$ ) from previous therapy, excluding alopecia, neuropathy, and hearing loss. Patients who previously received rapamycin analogs or were currently receiving any other investigational agents were excluded.

The study was conducted in accordance with the Declaration of Helsinki, Good Clinical Practice guidelines, and all local and federal regulations. The study protocol was approved by the Institutional Review Board or Ethics Review Committee at each participating site. Each patient's parent or legal guardian provided written informed consent, and patients provided assent according to local regulations.

\section{Study design and dose escalation}

This phase 1, multicenter, open-label study was conducted at a total of 8 study sites ( 3 study sites in the United States and 5 Innovative Therapies for Children with Cancer [ITCC] Consortium centers [2 in the United Kingdom and 3 in France]) between January 31, 2012, and the data cutoff, January 14, 2014 (ClinicalTrials. gov identifier NCT01431534; European Clinical Trials Database [EudraCT] number 2011-000729-55). An enteric-coated tablet formulation of ridaforolimus was orally administered for 5 consecutive days and not administered for 2 consecutive days per week in 28-day cycles until progression, unacceptable toxicity, or consent withdrawal. Patients who did not have disease progression, who adequately tolerated therapy, and who continued to meet eligibility criteria for 6 months after completion of the enrollment period were eligible to enter an extension phase of the study. Dose escalation was conducted by using a modified toxicity probability intervals method [41] that targeted a $30 \%$ DLT rate and started at $22 \mathrm{mg} /$ $\mathrm{m}^{2}$ (the equivalent of the adult RP2D [27], a 40-mg dose in adults with a BSA of $1.8 \mathrm{~m}^{2}$ ). The dose was escalated to $28 \mathrm{mg} / \mathrm{m}^{2}$ and $33 \mathrm{mg} / \mathrm{m}^{2}$ (increments of $25 \%$ of starting dose). Dosing was adjusted based on BSA and rounded to the nearest $10-\mathrm{mg}$ tablet. Patients were to be treated at sequentially rising dose levels until a preliminary MTD was identified.

\section{Safety assessments}

Toxicity was graded according to the National Cancer Institute Common Terminology Criteria for Adverse Events, version 4.0 [42]. Safety data were reported for all patients who received at least 1 dose of the study drug. A DLT was defined as any of the following events considered at least possibly related to the study drug and occurring during the first 28-day treatment cycle with adequate drug exposure (having received $>75 \%$ of planned doses, exclusive of study drug doses missed due to treatment-related toxicity): grade 3 to 4 neutropenia associated with fever, antibiotics, or hospitalization for infection; grade 4 thrombocytopenia requiring platelet transfusion; grade 4 neutropenia, grade 4 thrombocytopenia, or grade $\geq 3$ hyperglycemia persisting for $\geq 5$ days; grade $\geq 3$ diarrhea persisting $>24$ hours; grade $\geq 3$ nausea, vomiting, or other nonhematologic toxicity persisting despite optimal medical management (except transient electrolyte abnormalities, transient grade 3 liver function test result elevations, grade 3 neurotoxicity in patients who had grade 3 neurotoxicity at baseline, and hearing loss in patients who had grade 3 hearing loss at baseline); or any toxicity considered at least possibly related to the study drug that prevents completion of the DLT assessment period, or interrupts dosing (or delays the next cycle) for $>10$ dosing days. Once the RP2D of 
ridaforolimus was defined, an expansion cohort to be treated at the RP2D was planned to obtain additional safety, tolerability, and pharmacokinetic data.

\section{Pharmacokinetic assessments}

Whole blood samples (2 $\mathrm{mL}$ each) for pharmacokinetic analyses were collected at the following time points: $<5$ minutes before dosing on days 1 through 5 and at $0.5,1,2,4,8,24$, and 72 hours after drug administration on day 5 of the first week of the first treatment cycle. Blood concentrations of ridaforolimus were determined using a validated liquid chromatography/ tandem mass spectrometry assay as in previous ridaforolimus studies (Charles River Laboratories, Shrewsbury, MA) [25, 27]. The pharmacokinetic parameters of $\mathrm{AUC}_{0-24 \mathrm{~h}}$ and elimination half-life $\left(\mathrm{t}_{1 / 2}\right)$ were determined by noncompartmental modeling using WinNonlin software (Pharsight, Certara, Princeton, NJ).

\section{Efficacy assessments}

All patients were to have computed tomography or magnetic resonance imaging scans at baseline, every 2 cycles during treatment, and at the time of treatment discontinuation. Local investigator assessment of treatment response was performed using RECIST v1.1 [43].

\section{Statistical analyses}

Up to approximately 18 patients were to be treated during dose escalation depending on empirical safety data, with up to approximately 12 patients treated at the MTD (or maximum dose if the MTD was not achieved). Assuming that the standard deviation of the logarithm of the AUC of ridaforolimus is similar to that observed in adults at approximately 0.3 , with 10 patients the study would have approximately $96 \%$ power to rule out a $25 \%$ drop if the true AUC ratio were 1 , and approximately $74 \%$ power to rule out a $25 \%$ drop if the true AUC ratio were 0.9 , based on a type I error rate of 0.1 and a one-sided $t$ test.

At a safe and well-tolerated dose, ridaforolimus was considered to have obtained sufficient pharmacokinetic properties if the lower bound of the $90 \%$ one-sided confidence interval for the geometric mean $\mathrm{AUC}_{0-24 \mathrm{~h}}$ on day 5 , based on the one-sample $t$ test, exceeded 1,304 h॰ng/mL, or $75 \%$ of the estimated geometric mean $\mathrm{AUC}_{0-24 \mathrm{~h}}$ on day 5 after a dose of $40 \mathrm{mg}$ in adults $(1,739 \mathrm{~h} \bullet \mathrm{ng} / \mathrm{mL}$; data on file with ARIAD Pharmaceuticals, Inc./Merck \& Co., Inc.).

\section{ACKNOWLEDGMENTS}

We thank the patients, their families, their caregivers, and the investigators and their team members for participating in the trial, as well as Dr. L. Marshall and Dr. S. Gatz for extensive study management. Professional medical writing assistance was provided by Lela Creutz, PhD, at Peloton Advantage, LLC (Parsippany, New Jersey) and funded by ARIAD Pharmaceuticals, Inc. ADJP is funded through a Cancer Research UK Life Chair and Programme Grant included within a Cancer Research UK ICR Core Award (C347/A15403) and is supported from the NIHR RM/ICR Biomedical Research Centre and the Oak Foundation. DRH is supported by the National Institute for Health Research Biomedical Research Centre at Great Ormond Street Hospital for Children NHS Foundation Trust and University College London.

\section{CONFLICTS OF INTEREST}

S.G. DuBois has received drug supplies and research funding from Merck.

No potential conflicts of interest were disclosed by A.D.J. Pearson, S.M. Federico, I. Aerts, D.R. Hargrave, T.M. Trippett, or B. Geoerger.

R. Iannone and R.D. Geschwindt were previously employed by Merck.

R. Wang is employed by Merck.

F.G. Haluska was previously employed by and owned stock in ARIAD.

\section{FUNDING}

This study was sponsored by ARIAD Pharmaceuticals, Inc., and Merck \& Co., Inc.

\section{Authors' contributions}

Conception and design: A.D.J. Pearson, D.R. Hargrave, S.G. DuBois, R. Iannone, R.D. Geschwindt, B. Geoerger

Development of methodology: A.D.J. Pearson, D.R. Hargrave, R. Iannone, R.D. Geschwindt, B. Geoerger Acquisition of data: A.D.J. Pearson, S.M. Federico, I. Aerts, D.R. Hargrave, S.G. DuBois, R. Iannone, R.D. Geschwindt, B. Geoerger

Analysis and interpretation of data: All authors Writing, review, and/or revision of the manuscript: All authors

Study supervision: R. Iannone, R.D. Geschwindt

\section{REFERENCES}

1. Wullschleger $\mathrm{S}$, Loewith $\mathrm{R}$, Hall MN. TOR signaling in growth and metabolism. Cell. 2006; 124:471-484.

2. Shaw RJ, Cantley LC. Ras, PI(3)K and mTOR signalling controls tumour cell growth. Nature. 2006; 441:424-430.

3. Dancey JE. Therapeutic targets: $m$ TOR and related pathways. Cancer Biol Ther. 2006; 5:1065-1073.

4. Cully M, You H, Levine AJ, Mak TW. Beyond PTEN mutations: the PI3K pathway as an integrator of multiple 
inputs during tumorigenesis. Nat Rev Cancer. 2006; 6:184-192.

5. Mueller S, Phillips J, Onar-Thomas A, Romero E, Zheng S, Wiencke JK, McBride SM, Cowdrey C, Prados MD, Weiss WA, Berger MS, Gupta N, Haas-Kogan DA. PTEN promoter methylation and activation of the PI3K/Akt/ mTOR pathway in pediatric gliomas and influence on clinical outcome. Neuro Oncol. 2012; 14:1146-1152.

6. Barrett D, Brown VI, Grupp SA, Teachey DT. Targeting the PI3K/AKT/mTOR signaling axis in children with hematologic malignancies. Paediatr Drugs. 2012; 14:299-316.

7. Hütt-Cabezas M, Karajannis MA, Zagzag D, Shah S, Horkayne-Szakaly I, Rushing EJ, Cameron JD, Jain D, Eberhart CG, Raabe EH, Rodriguez FJ. Activation of $\mathrm{mTORC} 1 / \mathrm{mTORC} 2$ signaling in pediatric low-grade glioma and pilocytic astrocytoma reveals mTOR as a therapeutic target. Neuro Oncol. 2013; 15:1604-1614.

8. Houghton PJ, Morton CL, Kolb EA, Gorlick R, Lock R, Carol H, Reynolds CP, Maris JM, Keir ST, Billups CA, Smith MA. Initial testing (stage 1) of the mTOR inhibitor rapamycin by the Pediatric Preclinical Testing Program. Pediatr Blood Cancer. 2008; 50:799-805.

9. Wan X, Shen N, Mendoza A, Khanna C, Helman LJ. CCI779 inhibits rhabdomyosarcoma xenograft growth by an antiangiogenic mechanism linked to the targeting of mTOR/ Hif-1alpha/VEGF signaling. Neoplasia. 2006; 8:394-401.

10. Kurmasheva RT, Harwood FC, Houghton PJ. Differential regulation of vascular endothelial growth factor by Akt and mammalian target of rapamycin inhibitors in cell lines derived from childhood solid tumors. Mol Cancer Ther. 2007; 6:1620-1628.

11. Wan X, Mendoza A, Khanna C, Helman LJ. Rapamycin inhibits ezrin-mediated metastatic behavior in a murine model of osteosarcoma. Cancer Res. 2005; 65:2406-2411.

12. Mu X, Isaac C, Schott T, Huard J, Weiss K. Rapamycin inhibits ALDH activity, resistance to oxidative stress, and metastatic potential in murine osteosarcoma cells. Sarcoma. 2013; 2013:480713.

13. Geoerger B, Kieran MW, Grupp S, Perek D, Clancy J, Krygowski M, Ananthakrishnan R, Boni JP, Berkenblit A, Spunt SL. Phase II trial of temsirolimus in children with high-grade glioma, neuroblastoma and rhabdomyosarcoma. Eur J Cancer. 2012; 48:253-262.

14. Mascarenhas L, Meyer WH, Lyden E, Rodeberg DA, Indelicato DJ, Linardic CM, Anderson JR, Hawkins DS. Randomized phase II trial of bevacizumab and temsirolimus in combination with vinorelbine (V) and cyclophosphamide (C) for first relapse/disease progression of rhabdomyosarcoma (RMS): a report from the Children's Oncology Group (COG) [abstract 10003]. J Clin Oncol. 2014; 32 (May 20 suppl).

15. Metcalf CA III, Bohacek R, Rozamus LW, Burns KD, Roses JB, Rivera VM, Tang H, Keats JA, Dalgarno DC, Snodgrass J, Berstein DL, Weigele M, Clackson T. Structure-based design of AP23573, a phosphorous-containing analog of rapamycin for anti-tumor therapy [abstract 2476]. Cancer Res. 2004; 64:573.

16. Rivera VM, Squillace RM, Miller D, Berk L, Wardwell SD, Ning Y, Pollock R, Narasimhan NI, Iuliucci JD, Wang F, Clackson T. Ridaforolimus (AP23573; MK-8669), a potent mTOR inhibitor, has broad antitumor activity and can be optimally administered using intermittent dosing regimens. Mol Cancer Ther. 2011; 10:1059-1071.

17. Squillace RM, Miller D, Cookson M, Wardwell SD, Moran L, Clapham D, Wang F, Clackson T, Rivera VM. Antitumor activity of ridaforolimus and potential cell-cycle determinants of sensitivity in sarcoma and endometrial cancer models. Mol Cancer Ther. 2011; 10:1959-1968.

18. Chawla SP, Staddon AP, Baker LH, Schuetze SM, Tolcher AW, D'Amato GZ, Blay JY, Mita MM, Sankhala KK, Berk L, Rivera VM, Clackson T, Loewy JW, et al. Phase II study of the mammalian target of rapamycin inhibitor ridaforolimus in patients with advanced bone and soft tissue sarcomas. J Clin Oncol. 2012; 30:78-84.

19. Hartford CM, Desai AA, Janisch L, Karrison T, Rivera VM, Berk L, Loewy JW, Kindler H, Stadler WM, Knowles HL, Bedrosian C, Ratain MJ. A phase I trial to determine the safety, tolerability, and maximum tolerated dose of deforolimus in patients with advanced malignancies. Clin Cancer Res. 2009; 15:1428-1434.

20. Mita MM, Mita AC, Chu QS, Rowinsky EK, Fetterly GJ, Goldston M, Patnaik A, Mathews L, Ricart AD, Mays T, Knowles H, Rivera VM, Kreisberg J, et al. Phase I trial of the novel mammalian target of rapamycin inhibitor deforolimus (AP23573; MK-8669) administered intravenously daily for 5 days every 2 weeks to patients with advanced malignancies. J Clin Oncol. 2008; 26:361-367.

21. Seki Y, Yamamoto N, Tamura Y, Goto Y, Shibata T, Tanioka M, Asahina H, Nokihara H, Yamada Y, Shimamoto T, Noguchi K, Tamura T. Phase I study for ridaforolimus, an oral mTOR inhibitor, in Japanese patients with advanced solid tumors. Cancer Chemother Pharmacol. 2012; 69:1099-1105.

22. Mita MM, Britten CD, Poplin E, Tap WD, Carmona A, Yonemoto L, Wages DS, Bedrosian CL, Rubin EH, Tolcher AW. Deforolimus trial 106-a phase I trial evaluating 7 regimens of oral deforolimus (AP23573, MK-8669) [abstract 3509]. J Clin Oncol. 2008; 26 (May 20 suppl).

23. Demetri GD, Chawla SP, Ray-Coquard I, Le Cesne A, Staddon AP, Milhem MM, Penel N, Riedel RF, Bui-Nguyen B, Cranmer LD, Reichardt P, Bompas E, Alcindor T, et al. Results of an international randomized phase III trial of the mammalian target of rapamycin inhibitor ridaforolimus versus placebo to control metastatic sarcomas in patients after benefit from prior chemotherapy. J Clin Oncol. 2013; 31:2485-2492.

24. Iannone R, Yang Y, Elias A, Peylan-Ramu N, Judson I, Nunes J, Lee SY, Yun T, Ping S, Zhen W, Ebbinghaus S, Geschwindt R. Ridaforolimus as maintenance therapy 
in advanced sarcoma patients following clinical benefit from prior chemotherapy: pediatric data from the phase 3 Sarcoma Multi-Center Clinical Evaluation of the Efficacy of Ridaforolimus (SUCCEED) trial [abstract]. Pediatr Blood Cancer. 2012; 58:1081.

25. Gore L, Trippett TM, Katzenstein HM, Boklan J, Narendran A, Smith A, Macy ME, Rolla K, Narashimhan N, Squillace RM, Turner CD, Haluska FG, Nieder M. A multicenter, firstin-pediatrics, phase 1, pharmacokinetic and pharmacodynamic study of ridaforolimus in patients with refractory solid tumors. Clin Cancer Res. 2013; 19:3649-3658.

26. Frappaz D, Federico SM, Pearson AD, Gore L, Macy ME, DuBois SG, Aerts I, Iannone R, Geschwindt R, Van Schanke A, Wang R, Geoerger B. Phase 1 study of dalotuzumab monotherapy and ridaforolimus-dalotuzumab combination therapy in paediatric patients with advanced solid tumours. Eur J Cancer. 2016; 62:9-17.

27. Mita MM, Poplin E, Britten CD, Tap WD, Rubin EH, Scott BB, Berk L, Rivera VM, Loewy JW, Dodion P, Haluska F, Sarantopoulos J, Mita A, et al. Phase I/IIa trial of the mammalian target of rapamycin inhibitor ridaforolimus (AP23573; MK-8669) administered orally in patients with refractory or advanced malignancies and sarcoma. Ann Oncol. 2013; 24:1104-1111.

28. Spunt SL, Grupp SA, Vik TA, Santana VM, Greenblatt DJ, Clancy J, Berkenblit A, Krygowski M, Ananthakrishnan R, Boni JP, Gilbertson RJ. Phase I study of temsirolimus in pediatric patients with recurrent/refractory solid tumors. J Clin Oncol. 2011; 29:2933-2940.

29. Fouladi M, Laningham F, Wu J, O'Shaughnessy MA, Molina K, Broniscer A, Spunt SL, Luckett I, Stewart CF, Houghton PJ, Gilbertson RJ, Furman WL. Phase I study of everolimus in pediatric patients with refractory solid tumors. J Clin Oncol. 2007; 25:4806-4812.

30. Yee KW, Zeng Z, Konopleva M, Verstovsek S, Ravandi F, Ferrajoli A, Thomas D, Wierda W, Apostolidou E, Albitar M, O'Brien S, Andreeff M, Giles FJ. Phase I/II study of the mammalian target of rapamycin inhibitor everolimus (RAD001) in patients with relapsed or refractory hematologic malignancies. Clin Cancer Res. 2006; 12:5165-5173.

31. Reardon DA, Wen PY, Alfred Yung WK, Berk L, Narasimhan N, Turner CD, Clackson T, Rivera VM, Vogelbaum MA. Ridaforolimus for patients with progressive or recurrent malignant glioma: a perisurgical, sequential, ascending-dose trial. Cancer Chemother Pharmacol. 2012; 69:849-860.

32. Hurvitz SA, Andre F, Jiang Z, Shao Z, Mano MS, Neciosup SP, Tseng LM, Zhang Q, Shen K, Liu D, Dreosti LM, Burris HA, Toi $\mathrm{M}$, et al. Combination of everolimus with trastuzumab plus paclitaxel as first-line treatment for patients with HER2-positive advanced breast cancer (BOLERO-1): a phase 3, randomised, double-blind, multicentre trial. Lancet Oncol. 2015; 16:816-829.
33. Andre F, O’Regan R, Ozguroglu M, Toi M, Xu B, Jerusalem G, Masuda N, Wilks S, Arena F, Isaacs C, Yap YS, Papai Z, Lang I, et al. Everolimus for women with trastuzumab-resistant, HER2-positive, advanced breast cancer (BOLERO-3): a randomised, double-blind, placebocontrolled phase 3 trial. Lancet Oncol. 2014; 15:580-591.

34. Di Cosimo S, Sathyanarayanan S, Bendell JC, Cervantes A, Stein MN, Brana I, Roda D, Haines BB, Zhang T, Winter CG, Jha S, Xu Y, Frazier J, et al. Combination of the mTOR inhibitor ridaforolimus and the anti-IGF1R monoclonal antibody dalotuzumab: preclinical characterization and phase I clinical trial. Clin Cancer Res. 2015; 21:49-59.

35. Cardillo TM, Trisal P, Arrojo R, Goldenberg DM, Chang $\mathrm{CH}$. Targeting both IGF-1R and mTOR synergistically inhibits growth of renal cell carcinoma in vitro. BMC Cancer. 2013; 13:170.

36. Coulter DW, Blatt J, D'Ercole AJ, Moats-Staats BM. IGF-I receptor inhibition combined with rapamycin or temsirolimus inhibits neuroblastoma cell growth. Anticancer Res. 2008; 28:1509-1516.

37. Brana I, Berger R, Golan T, Haluska P, Edenfield J, Fiorica J, Stephenson J, Martin LP, Westin S, Hanjani P, Jones MB, Almhanna K, Wenham RM, et al. A parallel-arm phase I trial of the humanised anti-IGF-1R antibody dalotuzumab in combination with the AKT inhibitor MK-2206, the mTOR inhibitor ridaforolimus, or the NOTCH inhibitor MK-0752, in patients with advanced solid tumours. Br J Cancer. 2014; 111:1932-1944.

38. Rugo HS, Tredan O, Ro J, Morales S, Musolino A, Afonso N, Ferreira M, Park KH, Cortes J, Tan AR, Blum JL, Eaton L, Gause CK, et al. Results from the phase 2 trial of ridaforolimus, dalotuzumab, and exemestane compared to ridaforolimus and exemestane in advanced breast cancer [abstract PD5-1]. Cancer Res. 2015; 75 (suppl).

39. O'Reilly T, McSheehy PM. Biomarker development for the clinical activity of the mTOR inhibitor everolimus (RAD001): processes, limitations, and further proposals. Transl Oncol. 2010; 3:65-79.

40. Owonikoko TK, Khuri FR. Targeting the PI3K/AKT/ mTOR pathway: biomarkers of success and tribulation. Am Soc Clin Oncol Educ Book. 2013. doi: 10.1200/EdBook_ AM.2013.33.e395.

41. Ji Y, Li Y, Bekele BN. Dose-finding in phase I clinical trials based on toxicity probability intervals. Clin Trials. 2007; 4:235-244.

42. National Cancer Institute. Common Terminology Criteria for Adverse Events (CTCAE) v4.0. June 2010. NIH Publication No. 09-5410.

43. Eisenhauer EA, Therasse P, Bogaerts J, Schwartz LH, Sargent D, Ford R, Dancey J, Arbuck S, Gwyther S, Mooney M, Rubinstein L, Shankar L, Dodd L, et al. New response evaluation criteria in solid tumours: revised RECIST guideline (version 1.1). Eur J Cancer. 2009; 45:228-247. 